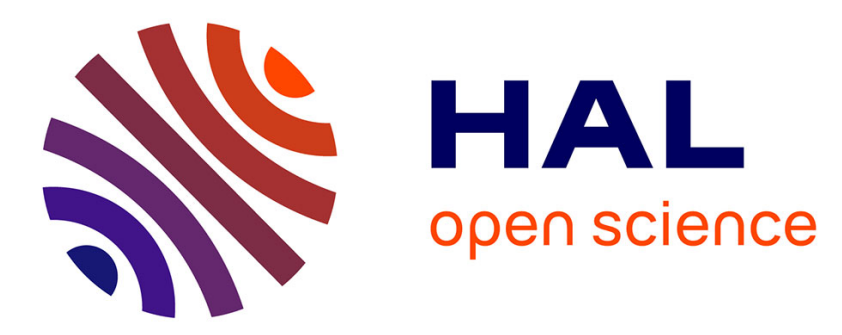

\title{
Methylparaben chlorination in the presence of bromide ions and ammonia: kinetic study and modeling
}

Pamela Abdallah, Florence Dossier-Berne, Nathalie Karpel Vel Leitner, Marie

Deborde

\section{- To cite this version:}

Pamela Abdallah, Florence Dossier-Berne, Nathalie Karpel Vel Leitner, Marie Deborde. Methylparaben chlorination in the presence of bromide ions and ammonia: kinetic study and modeling. Environmental Science and Pollution Research, 2021, 28 (24), pp.31256-31267. 10.1007/s11356-02011503-7 . hal-03411410

\author{
HAL Id: hal-03411410 \\ https://hal.science/hal-03411410
}

Submitted on 18 Nov 2021

HAL is a multi-disciplinary open access archive for the deposit and dissemination of scientific research documents, whether they are published or not. The documents may come from teaching and research institutions in France or abroad, or from public or private research centers.
L'archive ouverte pluridisciplinaire $\mathbf{H A L}$, est destinée au dépôt et à la diffusion de documents scientifiques de niveau recherche, publiés ou non, émanant des établissements d'enseignement et de recherche français ou étrangers, des laboratoires publics ou privés. 

MODELING

$11{ }^{1}$ Université de Poitiers, Institut de Chimie des Milieux et des Matériaux de Poitiers (IC2MP UMR 51115, 86073 Poitiers Cedex 9, France

23 *Corresponding author; email: marie.deborde@univ-poitiers.fr; phone: +33 549453924 


\section{Abstract}

2 The impacts of chlorination on methylparaben (MP) removal, as well as of bromide and ammonia

3 on the MP elimination kinetics were studied. Bromide and ammonia react with chlorine and are

4 promptly transformed into bromine and chloramines, respectively. Rate constants of chlorine,

5 bromine and monochloramine with MP were determined under different $\mathrm{pH}$ conditions. At $\mathrm{pH} 8.5$,

6 the apparent second-order rate constants of MP reactions with chlorine and bromine were found to

7 be $3.37( \pm 0.50) \times 10^{1}$ and $2.37( \pm 0.11) \times 10^{6} \mathrm{M}^{-1} \cdot \mathrm{s}^{-1}$ for $\mathrm{k}_{\text {Chlorine/MP }}$ and $\mathrm{k}_{\text {Bromine/MP, }}$ respectively, yet

8 there was low reactivity with monochloramine $\left(\mathrm{k}_{\mathrm{NH}_{2} \mathrm{Cl} / \mathrm{MP}}=0.045 \mathrm{M}^{-1} \cdot \mathrm{s}^{-1}\right)$. Regarding chlorination

9 and bromination, in order to gain further insight into the observed $\mathrm{pH}$-dependence of the reaction,

10 the elementary reactions were considered and the corresponding second-order rate constants were

11 calculated. The experimental and modeled values were quite consistent under these conditions.

12 Then chlorination experiments with different bromide and/or ammonia concentrations were

13 performed to assess the impact of inorganic water content on MP elimination and a kinetic model

14 was designed to assess MP degradation. Under these conditions, MP degradation was found to be

15 enhanced in the presence of bromide whereas it was inhibited in the presence of ammonia, and the 16 overall impact was $\mathrm{pH}$ dependent.

18 Keywords: Methylparaben, chlorine, bromide, ammonia, modeling

20 Abbreviations: pHBA, p-hydroxybenzoic acid; PCP, Personal care products; MP, Methylparaben; 21 PP, Propylparaben; WWTP, Wastewater treatment plant; THM, Trihalomethanes; EE2, 17 $\alpha-$ 22 ethynilestradiol; DOC, Dissolved organic carbon; HPLC, High performance liquid chromatography; 23 LOD, Limit of detection; LSODA, Livermore solver for ordinary differential equations; DPD, N,N 24 diethyl-p-phenylenediamine 


\section{Introduction}

2 Parabens are $p$-hydroxybenzoic acid (pHBA) esters with alkyl substituents belonging to methyl,

3 butyl or benzyl groups (Jonkers et al. 2010). They were first introduced as antimicrobial 4 preservatives in drug products in mid-1920s (Liebert 1984), while currently serving the same 5 purpose in cosmetics, toiletries, pharmaceuticals and foods (Daughton and Ternes 1999). By 1987, 6 over $7000 \mathrm{~kg} /$ year of parabens were used as additives in cosmetics and toiletries alone (Soni et al. 7 2005). That volume has increased over the last 20 years and parabens are nowadays found in 8 approximately $80 \%$ of personal care products (PCP) (Brausch and Rand 2011; Pouillot et al. 2006).

In the late 1990s, several studies confirmed the endocrine disrupting features of parabens as well as their links with diseases such as breast cancer particularly when found in cosmetics and PCP (Darbe et al. 2004; Oishi 2001; Routledge et al. 1998). Studies on prenatal exposure of pregnant women to parabens and potential impacts on anthropometric birth outcomes are ongoing (Jamal et al. 2019). Moreover, recent research highlighted the occurrence of these molecules in human body fluids and even breast milk, with methylparaben concentrations reaching 0.11-700 ng/mL (Dualde et al. 2019). Despite their controversial effects, and the emergence of paraben-free products, parabens (particularly methyl- (MP) and propylparaben (PP)) are still the most commonly used preservatives in PCP. Recent concern has been focused on the risks involved in human exposure to parabens. The industry estimated that adult and child exposure to parabens through the daily use of cosmetic products that may contain this compound could amount to $17.76 \mathrm{~g}$ and $0.378 \mathrm{~g}$, respectively (CIR 2008). In comparison to PCP parabens exposure, the daily intake of parabens from food was estimated to be low, i.e. about $1 \mu \mathrm{g} / \mathrm{kg}$ body weight/day (mean) and $3 \mu \mathrm{g} / \mathrm{kg}$ body weight/day (95th percentile) (Liao et al. 2013). Finally, in addition to direct contact, humans may be exposed to parabens in aquatic environments but also in swimming pools where parabens and their chlorinated transformation products have been detected (Terasaki and Makino 2008). 
1 Widespread production and use of parabens has led to their dissemination into the aquatic

2 environment through direct input in lakes, rivers or seawater when rubbed off bathers' skin during

3 recreational activities, or indirectly via effluents released from wastewater treatment plants

4 (WWTP). Parabens have actually also been detected in WWTP at concentrations ranging from 13

$5 \mu \mathrm{g} / \mathrm{L}$ in influents to $0.085 \mu \mathrm{g} / \mathrm{L}$ in effluents (Benjits et al. 2004; Canosa et al. 2006; Lee and Peart.

6 2005). In surface waters, the occurrence of parabens and their concentrations were found to be

7 highly season dependent, with maximum concentrations correlated with low flow conditions

8 (Loraine and Pettigrove 2006; Peng et al. 2008). Concentrations around $400 \mathrm{ng} / \mathrm{L}$ and $69 \mathrm{ng} / \mathrm{L}$ were

9 reported for methylparaben and propylparaben, respectively, in European rivers, whereas higher

10 methyl, ethyl, propyl and n-butylparaben concentrations of up to several $\mu \mathrm{g} / \mathrm{L}$ were detected in

11 Chinese and Brazilian rivers (Peng et al. 2008; Kasprzyk-Hordern and Dinsdale, 2008; González-

12 Mariño et al. 2009; Galinaro et al. 2015). Finally, reports concerning drinking water have been 13 contradictory, with some authors confirming their presence in tap water at $17( \pm 4) \mathrm{ng} / \mathrm{L}$

14 concentration, while others have denied this issue (Loraine and Pettigrove, 2006; Casas Ferreira and

15 Möder 2011). A recent study evaluating the amount of parabens in mineral and treated water 16 samples indicated methylparaben levels below $0.242 \mu \mathrm{g} / \mathrm{L}$, with $10 \mathrm{ng} / \mathrm{g}$ detected in drinking water 17 treatment sludge (Marta-Sanchez et al. 2018).

19 Chlorination is used in drinking water treatment and swimming pool disinfection. Studies on parabens chlorination would now be warranted since traces of parabens have been detected in 21 swimming pool water and in surface waters that serve as water resources for drinking water 22 production. Several studies have already shown that halogenated by-products can be generated 23 during the chlorination of parabens, some of which have been found in wastewaters, rivers and 24 swimming pools (Canosa et al. 2006; Terasaki and Makino 2008; González-Mariño et al. 2011; 25 Terasaki et al. 2012). Similarly, some kinetic parameters associated with the parabens chlorination have been described (Canosa et al. 2006; Terasaki et al. 2012; Mao et al. 2016; Yoom et al. 2018). 
1 Yet, in most studies only direct reactions of chlorine with parabens have been assessed while

2 overlooking the impact of constituents of the water matrix. Natural waters actually contain

3 dissolved organic matter along with various ions (bromide, ammonia, etc.) that could be involved in

4 chlorine consumption during disinfection steps. Bromide ions $\left(\mathrm{Br}^{-}\right)$have been detected in fresh

5 water environments at concentrations ranging from $\sim 10$ to $>1000 \mu \mathrm{g} / \mathrm{L}$ (Heeb et al. 2014).

6 Moreover, ammonia is found in waters with concentrations around $0.3 \mathrm{mg} / \mathrm{L}$. Bromine and

7 haloamines (particularly monochloramine $\left(\mathrm{NH}_{2} \mathrm{Cl}\right)$ ) can be formed as a result of $\mathrm{Br}^{-}$and ammonia

8 reactions with chlorine during chlorination steps in water treatment plants. Monochloramine is less

9 reactive than chlorine with organic compounds, whereas bromine is a highly reactive oxidant that

10 could contribute to organic compound degradation. According to published findings, the THM

11 formation rate and yield could actually be significantly increased during chlorination in the 12 presence of $\mathrm{Br}^{-}$(Symons et al. 1993).

13

14 The impact of chlorination on the elimination of one of the most common paraben PCP additives

15 (methylparaben (MP)) during disinfection steps was assessed in this study. This compound is found

16 in $48 \%$ of cosmetics and PCP (Masten 2005). Here we focused on the impact of $\mathrm{Br}^{-}$and ammonia

17 on MP removal during chlorination. Chlorination, bromination and chloramination of

18 methylparaben were studied at different $\mathrm{pH}$ levels. MP chlorination experiments were also

19 conducted in the presence of various $\mathrm{Br}^{-}$and ammonia concentrations and for different $\mathrm{pH}$ levels.

20 Under these conditions, a kinetic model was designed and a comparison between the simulation

21 data and our experimental findings was performed. The impacts of $\mathrm{Br}^{-}$and ammonia on $\mathrm{MP}$

22 removal during chlorination steps were discussed with respect to $\mathrm{MP}$, chlorine, $\mathrm{Br}^{-}$and ammonia

23 concentrations commonly found during the drinking water production process. 


\section{Material and methods}

\subsection{Chemical reagent}

3 Methylparaben (MP) (98\% purity) and 17 $\alpha$-ethynilestradiol (EE2) (98\% purity) were from Sigma

4 Aldrich and phenol was from ProLabo. Commercial sodium hypochlorite solution (13\%) was obtained from Acros Organics. Analytical grade phosphate buffers, sodium thiosulfate, and colorimetric agents were from Sigma Aldrich or Acros Organics.

Pure water from a MilliQ water purification system was used to prepare all stock solutions (18.2 $\mathrm{M} \Omega . \mathrm{cm}$ and DOC $<0.1 \mathrm{mg} / \mathrm{L})$. Bromine stock solutions were obtained by adding $0.55 \mathrm{mM}$ of potassium bromide $(\mathrm{KBr})$ to a $0.5 \mathrm{mM}$ ozone solution at $\mathrm{pH} 4(10 \mathrm{mM}$ phosphate) and at a temperature of $5^{\circ} \mathrm{C}$. $\mathrm{NaOH}$ was then used to adjust the storage solution $\mathrm{pH}$ to 11 . Free chlorine was slowly added to an ammonium chloride solution $\left(\mathrm{NH}_{4} \mathrm{Cl}\right)(2 \mathrm{~mol} / \mathrm{mol}$ nitrogen-to-chlorine ratio $)$ in a well-stirred reactor at $\mathrm{pH}=8.5$ to prepare the daily monochloramine stock solutions.

\subsection{Kinetic experiments}

Duplicate kinetic experiments were performed at room temperature $\left(20 \pm 2^{\circ} \mathrm{C}\right)$ in aqueous solutions in the presence of phosphate salts (ionic strength $2 \times 10^{-3} \mathrm{M}$ ), in the $\mathrm{pH} 6$ to 11 range (pH variation $<0.1$ under these conditions).

Chlorination kinetic experiments were conducted in the presence of excess free chlorine ([Chlorine $\left.]_{\mathrm{T}, 0}>10[\mathrm{MP}]_{\mathrm{T}, 0}\right)$ under pseudo-first-order conditions using HPLC-UV to measure the decrease in MP concentration. Chlorine concentration variations were found to be less than $5 \%$ throughout the reaction time under these conditions. Batch reactors $(1 \mathrm{~L})$ were used in these experiments. Chlorine stock solution $\left([\text { Chlorine }]_{\mathrm{T}, 0}>15 \mu \mathrm{M}\right)$ was added to the solution containing MP $(1 \mu \mathrm{M})$ to start the kinetic runs. Then, $1.5 \mathrm{~mL}$ of solution was sampled at different time intervals (0 to $60 \mathrm{~min})$, and placed in vials containing $20 \mu \mathrm{L}$ of sodium thiosulfate $(100 \mathrm{~g} / \mathrm{L})$. 
1 Residual chlorine was quenched and the reaction stopped under these conditions. The first-order

2 kinetics relative to chlorine were confirmed by varying the chlorine concentration under different

$3 \mathrm{pH}$ conditions. The monochloramine reactivity with MP was assessed using the same kinetic

4 method. The experiments were conducted in batch reactors (1 L) containing monochloramine stock

5 solutions $(2 \mathrm{mM})$ and the kinetic runs were started by adding MP stock solution $\left([\mathrm{MP}]_{\mathrm{T}, 0}=1 \mu \mathrm{M}\right)$.

6 At different time intervals (0 to $300 \mathrm{~min}$ ), samples were withdrawn and placed in vials containing

$720 \mu \mathrm{L}$ of sodium thiosulfate $(100 \mathrm{~g} / \mathrm{L})$ to quench residual monochloramine.

9 Bromination experiments were also performed to determine the rate constants of bromine with MP

10 in the light of the fact that chlorine reacts with $\mathrm{Br}^{-}$to yield bromine (Kumar and Margerum 1987).

11 For these experiments, the competitive kinetic method was used since bromine is much more

12 reactive than chlorine with organic compounds. This competitive method was conducted using two 13 reference compounds based on their similar reactivity with bromine, i.e. phenol and $17 \alpha-$ 14 ethynilestradiol (EE2). Different bromine doses (0 to $4.5 \mu \mathrm{M})$ were added in $50 \mathrm{~mL}$ batch reactors 15 containing equimolar quantities of MP and reference compound $(1 \mu \mathrm{M})$ in our experiments. HPLC16 UV was used to analyse the remaining MP and competitor (phenol or EE2) concentrations after 24 $17 \mathrm{~h}$ to confirm complete bromine consumption. The k 18 previously reported kOxidant/C (kOxidant/EE2 or kOxidant/phenol) values (Gallard et al. 2003; Lee and von 19 Gunten 2009).

\subsection{Chlorination experiments and kinetic modeling in the presence of $\mathrm{Br}$ and/or ammonia}

23 All chlorination experiments conducted in the presence of $\mathrm{Br}^{-}$and/or ammonia were carried out in batch reactors $(1 \mathrm{~L})$ buffered with phosphate salts to $\mathrm{pH} 7$ and 8.5 at initial chlorine and MP concentrations of $10 \mu \mathrm{M}$ and $2 \mu \mathrm{M}$, respectively. Concentrations ranging from 0 to $10 \mu \mathrm{M}$ were used for $\mathrm{Br}^{-}$and ammonia. 
2 For the kinetic modeling, all possible reactions in the presence of chlorine and $\mathrm{Br}^{-}$and/or ammonia

3 at $\mathrm{pH} 7$ and 8.5 were considered and the LSODA deterministic simulation method was used in the

4 Copasi software environment (Hoops et al. 2006). The model simulations were subsequently 5 compared to the experimental results obtained at $\mathrm{pH} 7$ and 8.5.

\subsection{Analytical methods}

8 Chlorine in commercial and stock solutions was quantified by iodometry (Rodier et al. 2009).

9 Concentration in the bromine stock solution was determined by measuring absorbance at $329 \mathrm{~nm}(\boldsymbol{\varepsilon}$

$10=332 \mathrm{M}^{-1} \mathrm{~cm}^{-1}$ ) with a VARIAN Cary 50 UV/VIS spectrophotometer (Troy and Margerum, 1991).

11 During the chlorination experiments, the DPD colorimetric method (Rodier et al. 2009) was

12 followed for chlorine concentration determination and an SAFAS spectrophotometer was used to 13 measure the absorbance at $510 \mathrm{~nm}\left(\varepsilon=14550 \mathrm{M}^{-1} \mathrm{~cm}^{-1}\right.$; LOD $\left.=0.5 \mu \mathrm{M}\right)$. pH measurements were 14 obtained using a MeterLab pH-meter fitted with a Radiometer Analytical combination $\mathrm{pH}$ electrode.

16 MP, phenol and EE2 were analyzed with an Alliance Waters 2695 HPLC system (pump and 17 autosampler) combined with a UV Visible Waters 2487 detector and by using a C18 Kromasil 18 column $(250 \mathrm{~mm} \times 4.6 \mathrm{~mm}, 5 \mu \mathrm{m})$. The eluent used at $1 \mathrm{~mL} / \mathrm{min}$ flow rate for HPLC analysis had a 19 methanol/purified water ratio of $55 / 45$ for MP and phenol or had a $0.1 \%$ acetic acid 20 methanol/purified water ratio of $70 / 30$ for EE2. The injection volume for each sample was $100 \mu \mathrm{L}$ 21 and the UV detection wavelength was set at $254 \mathrm{~nm}$ for MP, $255 \mathrm{~nm}$ for phenol and $270 \mathrm{~nm}$ for 22 EE2.

\section{Results and discussion}


1 All chlorination and chloramination experiments were conducted in the presence of an excess

2 oxidant concentration. Under these conditions, apparent second-order rate constants ranging from $31.90( \pm 0.10) \times 10^{-1}$ to $4.60( \pm 0.10) \times 10^{1} \mathrm{M}^{-1} \cdot \mathrm{s}^{-1}$ were obtained in the 6 to $10 \mathrm{pH}$ range during

4 chlorination, whereas we observed low chloramine reactivity with MP with a second-order rate 5 constant of $0.045 \mathrm{M}^{-1} \cdot \mathrm{s}^{-1}$ at $\mathrm{pH}$ 8.5. This latter result was in the same order of magnitude as those 6 obtained previously for phenolic compounds (Abdallah et al. 2015; Cimetière et al. 2009). No other $7 \mathrm{pH}$ level was tested during chloramination due to this low reactivity with MP. Regarding bromine, experiments based on the competitive kinetic method were performed and apparent second-order

9 rate constants between $2.26( \pm 0.14) \times 10^{4}$ and $3.35( \pm 0.11) \times 10^{6} \mathrm{M}^{-1} . \mathrm{s}^{-1}$ were found in the 6 to 11 $\mathrm{pH}$ range.

12 Fig. 1 shows the variations obtained in the apparent second-order rate constants of chlorine $13\left(\mathrm{k}_{\text {Chlorine/MP }}\right)$ and bromine $\left(\mathrm{k}_{\mathrm{Bromine}} \mathrm{MP}\right)$ as a function of the $\mathrm{pH}$. Similar profiles are obtained for both 14 oxidants, with maximum $\mathrm{k}_{\text {oxidant/MP }}$ values noted at $\mathrm{pH} 8$ for chlorination and $\mathrm{pH} 8.6$ for 15 bromination. These $\mathrm{pH}$ profiles could be explained by taking the ionized and neutral MP species 16 and the different chlorine or bromine forms into account. Accordingly, a kinetic model was 17 designed to predict variations in $\mathrm{k}_{\text {Chlorine/MP }}$ and $\mathrm{k}_{\mathrm{Bromine} / \mathrm{MP}}$ apparent rate constants according to the $18 \mathrm{pH}$. Table 1 gives a list of $\mathrm{HOX}$ and $\mathrm{XO}^{-}$reactions with neutral and ionized forms of MP that were 19 considered in the model simulations. In this Table, $\mathrm{X}$ represents $\mathrm{Cl}$ or $\mathrm{Br}$, respectively, for 20 chlorination or bromination experiments. For both oxidants, $\mathrm{X}_{2} \mathrm{O}$ and $\mathrm{X}_{2}$ reactivity was neglected 21 since the chlorination reaction did not differ from a first-order reaction relative to chlorine, and 22 chlorine and bromine had high rate constants (Heeb et al. 2014; Sivey et al. 2010). Under these 23 conditions, since MP has second-order reactions with chlorine and bromine, and following a similar 24 rationale as that outlined in Abdallah et al. (2015), kOxidant/MP could be formulated as follows:

$$
\mathrm{k}_{\text {Oxidant } / \mathrm{MP}}=\frac{\mathrm{k}_{1}\left[\mathrm{H}^{+}\right]^{2}+\mathrm{k}_{2} \mathrm{~K}_{\mathrm{a} 2}\left[\mathrm{H}^{+}\right]+\mathrm{k}_{3}\left[\mathrm{H}^{+}\right] \mathrm{K}_{\mathrm{a} 1}+\mathrm{k}_{4} \mathrm{~K}_{\mathrm{a} 1} \mathrm{~K}_{\mathrm{a} 2}}{\left(\left[\mathrm{H}^{+}\right]+\mathrm{K}_{\mathrm{a} 2}\right)\left(\left[\mathrm{H}^{+}\right]+\mathrm{K}_{\mathrm{a} 1}\right)}
$$


1 For each oxidant, the rate constants of elementary reactions 3 to 6 (i.e. $k_{1}, k_{2}, k_{3}$ and $k_{4}$ ) were

2 determined via non-linear least-square regression of the experimental data using the Sigma Plot

311.0 software package. The thus obtained elementary rate constants are shown in Table 1 . For these

4 rate constants, the experimental and modeled values were closely correlated for both chlorination

5 and bromination, as shown in Fig. 1, thus validating the proposed reaction system. Under these

6 conditions, for a $\mathrm{pH}$ range between 7 and 9, the overall reaction seemed to be mainly controlled by

7 the elementary reaction between the ionized form of MP and the protonated form of the oxidant

8 (HOX), leading to a maximum apparent rate constant for $\mathrm{pH}=\left(\mathrm{pKa}_{1}+\mathrm{pKa} 2\right) / 2$. This trend was in

9 line with previously reported findings on phenolic compound chlorination and bromination

10 (Abdallah et al. 2015; Deborde and von Gunten, 2008). Moreover, as previously observed by Yoom

11 et al. (2018), we found that bromine was four orders of magnitude more reactive with MP compared

12 to chlorine at $\mathrm{pH}$ 7. Fig. $1 \mathrm{c}$ shows the half-life patterns according to $\mathrm{pH}$ for the $[\text { Oxidant }]_{\mathrm{T}}=14 \mu \mathrm{M}$

$13\left([\text { Chlorine }]_{\mathrm{T}}=1 \mathrm{mg} / \mathrm{L} ;[\text { Bromine }]_{\mathrm{T}}=2.2 \mathrm{mg} / \mathrm{L}\right)$ constant values. Under these conditions, the half-

14 lives of $32.5 \mathrm{~min}$ and $0.27 \mathrm{~s}$ at $\mathrm{pH} 7$ were calculated for chlorination and bromination, respectively.

16 The highest rate constants observed for elementary reactions with the ionized species of MP $\left(\mathrm{k}_{2}>\mathrm{k}_{1}\right.$

17 and $\mathrm{k}_{4}>\mathrm{k}_{3}$ for $\mathrm{HOX}$ and $\mathrm{XO}^{-}$respectively) could be attributed to the higher electron donor feature of

18 the phenolate function that is conducive to electrophilic attack of chlorine or bromine. As

19 previously shown with regard to various phenolic compounds, this could be illustrated by

20 comparing the elementary rate constant $\mathrm{k}_{2}$ to the Hammett constants of the substituents that reflect

21 the electronic density of the aromatic ring (Heeb et al. 2014; Gallard et al. 2003; Lee and von

22 Gunten 2009; Abdallah et al. 2015; Duirk and Bridenstine 2013; Deborde and von Gunten 2008;

23 Guo and Lin 2009; Rebenne et al. 1996). Fig. 2 shows these correlations based on the reactivity of

24 protonated forms of chlorine and bromine $(\mathrm{HOCl}$ and $\mathrm{HOBr})$ versus Hammett constants $\left(\sigma_{\mathrm{o}, \mathrm{m}, \mathrm{p}}\right)$ for

25 various mono- and di-substituted phenols according to Duirk et al. (2013) and Heeb et al. (2014). In

26 this Figure, $\sigma_{o, m, p}$ were calculated on the basis of previously reported values (Hansch and Leo 1995; 
1 Hansch and Leo 1991), while the kinetic data were obtained from various studies (Gallard et al.

2 2003; Abdallah et al. 2015; Deborde and von Gunten 2008; Rebenne et al. 1996; Gallard and von

3 Gunten 2002; Pattison and Davies 2004; Echigo 2002; Acero et al. 2005). The negative slope

4 plotted for both oxidants (chlorine and bromine) was consistent with the electrophilic substitution

5 mechanism. Concerning chlorination, two different correlations were obtained for substituted

6 phenols and dihydroxybenzenes, indicating that for the same $\sum \sigma_{(0, m, p)}$ values, the substituted

7 dihydroxybenzene rate constants were more than one order of magnitude higher than those of

8 substituted phenols, as expected from the higher sensitivity of dihydroxybenzenes towards $\mathrm{HOCl}$

9 substitution (Deborde and von Gunten 2008; Gallard and von Gunten 2002). There was close

10 agreement between the $\mathrm{k}_{2}$ rate constants obtained for MP chlorination and bromination and

11 Hammett-type correlations for phenolic compound chlorination and bromination, as shown in Fig.

12 2. Accordingly, it was assumed that there was a similar mechanism based on electrophilic

13 substitution on the ortho positions to the phenol during MP chlorination or bromination. The

14 formation of mono and dihalogenated derivatives was thus expected. Such transformation products

15 were previously reported by Canosa et al. (2006), Terasaki and Makino (2008), González-Mariño et

16 al. 2011, Teraski et al. (2012 and Yoom et al. (2018).

\subsection{Impacts of Br/ammonia on MP chlorination and kinetic modeling}

19 Chlorination experiments were conducted in the presence of $\mathrm{Br}^{-}$and/or ammonia at $\mathrm{pH} 7$ and 8.5.

20 The results are illustrated in Fig. 3 for $\mathrm{pH} 7$ and Fig. 4 for $\mathrm{pH}$ 8.5. Kinetic modeling was undertaken

21 using Copasi software (Hoops et al. 2006) to simulate the experimental results for MP removal

22 under these conditions. The 12 reactions listed in Table 2 were considered in this modeling. First

23 transformation product reactions with chlorine and bromine were taken into account since they can

24 lead to oxidant consumption. In the case of monochloramine, reactions with the transformation

25 products were overlooked based on its low reactivity with phenolic compounds. Similarly, reactions

26 of other haloamines with MP (and the transformation products) were assumed to be negligible as 
1 previously noted by Abdallah et al. (2015). For these haloamines, low concentrations were actually

2 expected according to Luh and Mariñas model (Luh and Mariñas 2014) (i.e. $<10^{-7} \mathrm{M}$ for

3 dichloramine, trichloramine and bromamines, at $\mathrm{pH} 7$ for $[\text { Chlorine }]_{\mathrm{T}, 0}=10 \mu \mathrm{M}$ and $\left[\mathrm{NH}_{4}{ }^{+}\right]=\left[\mathrm{Br}^{-}\right]$

$4=1 \mu \mathrm{M})$. In addition, these species were generated slowly under our experimental conditions.

5 Finally, $\mathrm{BrCl}$ and $\mathrm{BrOCl}$ reactions were overlooked since the concentrations of these species were several orders of magnitude lower than those of $\mathrm{HOBr}$ under our $\mathrm{pH}$ conditions, and regarding the high $\mathrm{HOBr}$ reactivity with MP (Heeb et al. 2014). Calculations were conducted considering the Hammett correlations described previously in Fig. 2 in order to determine the $\mathrm{k}_{2}$ elementary rate constants for halogenated MP products (Heeb et al. 2014; Duirk et al. 2013). The apparent rate constants at $\mathrm{pH} 7$ and 8.5 were obtained from the simplified equation 1, while considering the HOX reaction with the ionized species of each compound as being the major reaction yet without including the other reactive forms over the considered $\mathrm{pH}$ range (7-8.5).

Fig. 3a and 3c illustrate the findings of the experiments conducted at $\mathrm{pH} 7$ in the presence of $\mathrm{Br}^{-}$or ammonia. Faster MP degradation occurred in the presence of $\mathrm{Br}^{-}$, due to the higher rate constants of bromination compared to chlorination. After a 10 min reaction time, the MP concentration decreased by $21 \%$ in the absence of $\mathrm{Br}^{-}$compared to approximately $50 \%, 75 \%$ and $100 \%$ in the presence of 1, 2 and $5 \mu \mathrm{M} \mathrm{Br}^{-}$, respectively. However, in the presence of ammonia, a decrease in MP elimination during chlorination was observed with increasing ammonia concentrations due to chlorine reaction with ammonia, thus yielding chloramines which are known to have lower

21 reactivity. Total inhibition of MP elimination was observed in the presence of high ammonia concentrations $(10 \mu \mathrm{M})$. With the proposed reaction system and rate constants, there was close agreement between the experimental data and the model simulations (Fig. 3a and 3c). The kinetic model was therefore also used to simulate the oxidant variation patterns during the chlorination experiments conducted in the presence of $\mathrm{Br}^{-}$or ammonia. As seen in Fig. 3b, the increase in $\mathrm{Br}^{-}$ concentrations led to a decrease in free available chlorine concentration due to the reaction between 
$1 \mathrm{HOCl}$ and $\mathrm{Br}^{-}$. At $\mathrm{pH} 7$, rapid bromine formation was noted followed by its elimination due to its

2 reaction with phenolic compounds (MP and transformation products). An increase in bromine

3 concentration was then expected when substantial MP removal was observed $([\mathrm{Br}-]=5 \mu \mathrm{M} ; \mathrm{t}=2$

$4 \mathrm{~min}$ ). Fast initial chlorine consumption leading to chloramine formation was observed in the

5 presence of increasing ammonia concentrations (without $\mathrm{Br}^{-}$; Fig. 3d). Monochloramine

6 decomposition was slow, as reflected by the low reactivity of monochloramine $\left(\mathrm{NH}_{2} \mathrm{Cl}\right)$ with MP.

7 All chloramine decomposition reactions were not considered in Table 2. However, complementary

8 modeling tests were conducted by taking into account complete chloramine decomposition reaction

9 systems according to Luh and Mariñas (2014) and Vikesland et al. (2001). The results obtained

10 under these conditions were in line with those shown in Fig. 3.

12 Fig. 4a 4b, 4c and 4d represent MP chlorination experiments performed in the presence of $\mathrm{Br}^{-}$or 13 ammonia at $\mathrm{pH}$ 8.5. Results similar to those obtained at $\mathrm{pH} 7$ were obtained in both experiments in 14 the presence of $\mathrm{Br}^{-}$or ammonia, i.e. an increase in MP elimination in the presence of $\mathrm{Br}^{-}$and a 15 decrease in MP decay in the presence of ammonia. However, at $\mathrm{pH} 8.5$, a lower rate constant for the 16 chlorine reaction with $\mathrm{Br}^{-}\left(\mathrm{k}_{\mathrm{HOCl} / \mathrm{Br}^{-}}=153 \mathrm{M}^{-1} \cdot \mathrm{s}^{-1}\right.$ at $\mathrm{pH} 8.5$ versus $1200 \mathrm{M}^{-1} \cdot \mathrm{s}^{-1}$ at $\left.\mathrm{pH} 7\right)$ and a higher bromine reactivity with MP (and transformation products) lead to slower bromine formation and faster consumption during the experiments performed at $\mathrm{pH} 8.5$ in the presence of $\mathrm{Br}^{-}$.

19 Consequently, lower bromine concentrations were expected compared to those predicted at $\mathrm{pH} 7$ 20 and an increase in bromine concentration was expected only when significant MP elimination was 21 achieved $\left(\left[\mathrm{Br}^{-}\right]=5 \mu \mathrm{M} ; \mathrm{t}=10 \mathrm{~min}\right)$. In parallel, in the presence of ammonia, there was more rapid 22 monochloramine formation at $\mathrm{pH} 8.5$ due to the higher rate constant of the reaction between 23 chlorine and ammonia $\left(\mathrm{k}_{\mathrm{HOCl} / \mathrm{NH}_{3}}=1.33 \times 10^{4} \mathrm{M}^{-1} \cdot \mathrm{s}^{-1}\right.$ at $\mathrm{pH} 7$ compared to $4.58 \times 10^{4} \mathrm{M}^{-1} \cdot \mathrm{s}^{-1}$ at $\mathrm{pH}$ 24 8.5). 
1 Finally, Fig. 3e, 3f, 4e and 4f show results obtained for experiments performed in the simultaneous

2 presence of ammonia and $\mathrm{Br}^{-}$. Under these conditions, a good correlation that supported the

3 proposed reaction system was obtained between the experimental data and the model simulations

4 for both studied $\mathrm{pH}$ levels. For a given $\mathrm{Br}^{-}$concentration, the inhibitory effect due to chlorine

5 consumption and chloramines formation was progressively observed as the ammonia concentration

6 increased, regardless of the considered $\mathrm{pH}$. However, in the presence of ammonia, the promoting

7 effect of bromine formation on MP degradation was more or less favored according to the pH level

8 (Fig. 3e and 4e). Accordingly, in the presence of equal quantities of $\mathrm{Br}^{-}$and ammonia, the overall

9 effect on MP elimination was $\mathrm{pH}$ dependent. After 10 min reaction time in the presence of $\left[\mathrm{Br}^{-}\right]=$

$10\left[\mathrm{NH}_{4}{ }^{+}\right]=10 \mu \mathrm{M}, \mathrm{MP}$ removal was close to $50 \%$ at $\mathrm{pH} 7$ whereas only $10 \% \mathrm{MP}$ removal was

11 observed at $\mathrm{pH}$ 8.5. Hence, the promoting effect of $\mathrm{Br}^{-}$was more marked at $\mathrm{pH} 7$ while ammonia

12 had a predominant inhibitory effect at $\mathrm{pH}$ 8.5. The higher rate constant of the chlorine-bromide

13 reaction at $\mathrm{pH} 7$, leading to a faster bromine formation $\left(\mathrm{k}_{\mathrm{Chlorine} / \mathrm{Br}^{-}}=1200 \mathrm{M}^{-1} \cdot \mathrm{s}^{-1}\right.$ at $\mathrm{pH} 7$ versus

$14153 \mathrm{M}^{-1} \cdot \mathrm{s}^{-1}$ at $\mathrm{pH} 8.5$ ), together with the slight decrease of the rate constant of the chlorine-ammonia

15 reaction at $\mathrm{pH} 7$ compared to $\mathrm{pH} 8.5\left(\mathrm{k}_{\text {Chlorine } / \mathrm{NH}_{3}}=1.33 \times 10^{4} \mathrm{M}^{-1} \cdot \mathrm{s}^{-1}\right.$ at $\mathrm{pH} 7$ versus $4.58 \times 10^{4} \mathrm{M}^{-}$

$16{ }^{1} \cdot \mathrm{s}^{-1}$ at $\mathrm{pH} 8.5$ ), could partially explain this phenomenon (as shown in Fig. 3f, 4f).

MP decay after 10 min chlorination in the presence of different $\mathrm{Br}^{-}$and ammonia concentrations was estimated in Fig. 5 based on the reactions reported in Table 2. These results showed that, for given $\mathrm{Br}^{-}$and ammonia concentrations, the overall impact could differ significantly according to the

$21 \mathrm{pH}$ considered. At $\mathrm{pH} 7$, the promoting effect of $\mathrm{Br}^{-}$prevailed over the inhibitory effect of ammonia. Consequently, MP removal by bromine was favored during chlorination in the presence of $\mathrm{Br}^{-}$under water treatment conditions, which could lead to the formation of brominated transformation products. These latter compounds are usually more toxic than chlorinated byproducts (Chisholm et al. 2008; Sharma et al. 2014; Zhai et al. 2014). 


\section{Conclusion}

2 Chlorine was shown to be an efficient oxidant for MP elimination, with apparent rate constants of

3 up to $33.7 \mathrm{M}^{-1} \cdot \mathrm{s}^{-1}$ at $\mathrm{pH}$ 8.5. In the presence of $\mathrm{Br}^{-}$and ammonia (e.g. under water treatment

4 conditions), chlorine is consumed as a result of $\mathrm{Br}^{-}$producing bromine or of ammonia producing chloramines. Bromine was shown to be highly reactive with MP, with an apparent rate constant of $2.37 \times 10^{6} \mathrm{M}^{-1} \cdot \mathrm{s}^{-1}$ at $\mathrm{pH} 8.5$, whereas low monochloramine reactivity was noted. Accordingly, during chlorination in the presence of $\mathrm{Br}^{-}$, MP elimination could be induced by bromine and the formation of brominated transformation products—assumed to be more toxic_-could potentially be observed. In the presence of ammonia, partial or total inhibition of MP elimination could occur. Finally, in the presence of both $\mathrm{Br}^{-}$and ammonia (e.g. under water treatment conditions) the overall impact is $\mathrm{pH}$ dependent. For given $\mathrm{Br}^{-}$and ammonia concentrations, a more relevant inhibiting impact of ammonia at $\mathrm{pH} 8.5$ is observed due to the fast chlorine consumption, compared to a more pronounced promoting effect of $\mathrm{Br}^{-}$which resulted in rapid bromine formation at $\mathrm{pH}$. In this study, a kinetic model considering the different possible reactions was designed to predict methylparaben removal during chlorination in the presence of $\mathrm{Br}^{-}$and ammonia. This model could be used to assess other alkyl parabens which include alkyl substituents with similar electronic effects. Based on Hammett-type correlations, the method described in this study could also be used to estimate the removal of other phenolic compounds during the water chlorination steps.

\section{Acknowledgements}

The authors thank the European Community (FEDER) and the French Poitou-Charentes Region for financial support. Moreover, we especially thank Ayan Aden Mousa for her assistance in this study. 


\section{References}

Abdallah P, Deborde M, Dossier Berne F, Karpel Vel Leitner N (2015) Kinetics of chlorination of benzophenone-3 in the presence of bromide and ammonia. Environmental Science and Technology 49:14359-14367

Acero JL, Piriou P, von Gunten U (2005) Kinetics and mechanisms of formation of bromophenols during drinking water chlorination: assessment of taste and odor development. Water Research 39:2979-2993

Benjits T, Lambert W, De Leenheer A (2004) Analysis of multiple endocrine disruptors in environemental water via wide-spectrum solid-phase extraction and dual-polarity ionization LC-ion trap-MS/MS. Analytical Chemistry 76:704-711.

Brausch JM, Rand GM (2011) A review of personal care products in the aquatic environment: environmental concentrations and toxicity. Chemosphere 82:1518-1532

Canosa P, Rodríguez I, Rubí E, Negreira N, Cela R (2006) Formation of halogenated by-products of parabens in chlorinated water. Analytica Chimica Acta 575:106-113

Casas Ferreira AM, Möder M, Fernández Laespada ME (2011) GC-MS determination of parabens, triclosans and methyl triclosan in water by in situ derivatization and stir-bar sorptive extraction. Analytical and Bioanalytical Chemistry 399:945-953

Chisholm K, Cook A, Bower C, Weinstein P (2008) Risk of birth defects in Australian communities with high levels of brominated disinfection by-products., Environmental Health Perspective $116: 1267-1273$

Cimetiere N, Dossier-Berne F, De Laat J (2009) Monochloramination of resorcinol: mechanism and kinetic modeling. Environmental Science and Technology 43:9380-9385

CIR (2008) Safety Review. Cosmetic Ingredient Review. Washington DC

Darbre PD, Aljarrah A, Miller WR, Coldham NG, Sauer MJ, Pope GS (2004) Concentrations of parabens in human breast tumors. Journal of Applied Toxicology 24:5-13 
Daughton CG, Ternes TA (1999) Pharmaceuticals and personal care products in the environment: agents of subtle change? Environmental Health Perspective 107:907-938

Dualde P, Pardo O, Fernández SF, Pastor A, Yusà V(2019) Determination of four parabens and bisphenols A, F and S in human breast milk using QuEChERS and liquid chromatography coupled to mass spectrometry. Journal of Chromatography B 1114-1115:154-166

Deborde M, von Gunten U (2008) Reactions of chlorine with ionorganic and organic compounds during water treatment - kinetics and mechanisms: A critical review. Water Research 42:1351

Duirk SE, Bridenstine DR, Leslie DC (2013) Reaction of benzophenone UV filters in the presence of aqueous chlorine: kinetics and chloroform formation. Water Research 47:579-587

Echigo S (2002) Kinetics and speciation of brominated disinfection by-products during ozonation. Ph.D. Thesis, University of Illinois, Urbana-Champaign

Echigo S, Minear RA (2006) Kinectics of the reaction of hypobromous acid and organic matters in water treatment processes. Water Science and Technology 53:235-243

Galinaro CA, Pereira FM, Vieira EM (2015) Determination of parabens in surface water from Mogi Guaçu River (Sao Paulo, Brazil) using dispersive liquid-liquid microextraction based on low density solvent and LC-DAD. Journal of the Brazilian Chemical Society 26:2205-2213

Gallard H, Pellizzari F, Croué JP, Legube B (2003) Rate constants of reactions of bromine with phenols in aqueous solution. Water Research 37:2883-2892

Gallard H, von Gunten U (2002) Chlorination of phenols: kinetics and formation of chloroform. Environmental Science and Technology 36:884-890

González-Mariño I, Quintana JB, Rodríguez I, Cela R (2009) Simultaneous determination of parabens, triclosan and triclocarban in water by liquid chromatography ionization tandem mass spectrometry. Rapid Communications in Mass Spectrometry 23:1756-1766

González-Mariño I, Quitana JB, Rodríguez I, Cela R (2011) Evaluation of the occurrence and biodegradation of parabens and halogenated by-products in wastewater by accurate-mass 
liquid chromatography-quadrupole-time-of-flight-mass spectrometry (LC-QTOF-MS). Water Research 45:6770-6780

3 Guo G, Lin F (2009) The bromination kinetics of phenolic compounds in aqueous solution. Journal of Hazardous Materials 170:645-651

Hansch C, Leo A, Hoekman DH (1995) Exploring QSAR: Fundamentals and applications in chemistry and biology. American Chemical Society, Washinghton DC

Hansch C, Leo A, Taft RW (1991) A survey of hammett substituent constants and resonance and field parameters. Chemical Reviews 91:165-195

Heeb MB, Criquet J, Zimmermann-Steffens SG, von Gunten U (2014) Oxidative treatment of bromide-containing waters: Formation of bromine and its reactions with inorganic and organic compounds - A critical review. Water Research 48:15-42

Hoops S, Sahle S, Gauges R, Lee C, Pahle J, Simus N, Singhal M, Xu L, Mendes P, Kummer U (2006) COPASI- a Complex Pathway Simulator. Bioinformatics 22:3067-3074

Jamal A, Rastkari N, Dehghaniathar R, Aghaei M, Nodehi RN, Nasseri S, Kashani H, Yunesian M (2019) Prenatal exposure to parabens and anthropometric birth outcomes: a systematic review. Environmental Research 173:419-431

Jonkers N, Sousa A, Galante-Oliveira S, Barroso CM, Kohler HPE, Giger W (2010) Occurrence and sources of selected phenolic endocrine disruptors in Ria de Aveiro, Portugal. Environmental Science and Pollution Research 17:834-843

Jonsson M, Lind J, Eriksen TE, Merényi G (1993) O-H bond strengths and one-electron reduction potentials of multisubstituted phenols and phenoxyl radicals. Predictions using free energy relationships. Journal of the Chemical Society, Perkin Transactions 2, 2:1567-1568

Kasprzyk-Hordern B, Dinsdale RM, Guwy AJ (2008) The occurrence of pharmaceuticals, personal care products, endocrine disruptors and illicit drugs in surface water in South Wales, UK., Water Research 42:3498-3518 
1 Kumar K, Margerum DW (1987) Kinetics and mechanism of general-acid-assisted oxidation of bromide by hypochlorite and hypochlorous acid. Chemistry 26: 2706-2711

3 Lee HB, Peart TE, Svoboda ML (2005) Determination of endocrine-disrupting phenols, acidic pharmaceuticals and personal-care products in sewage by solid-phase extraction and gas chromatography-mass spectrometry. Journal of Chromatography A 1094:122129

Lee Y, von Gunten U (2009) Transformation of 17alpha-ethinylestradiol during water chlorination effects of bromide on kinetics, products and transformation pathways. Environmental Science and Technology 43:480-487

Liao C, Lee S, Moon HB, Yamashita N, Kannan K (2013) Parabens in sediment and sewage sludge from the United States, Japan and Korea: spatial distribution and temporal trends. Environmental Science and Technology 47:10895-10902

Liebert N (1984) Final Report on the Safety Assessment of Methylparaben, Ethylparaben, Propylparaben and Butylparaben International Journal of Toxicology 3:147-209

Loraine GA, Pettigrove ME (2006) Seasonal variations in concentrations of pharmaceuticals and personal care products in drinking water and reclaimed wastewater in southern Califormnia. Environmental Science and Technology 40:687-695

Luh J, Mariñas BJ (2014) Kinetics of bromochloramine formation and decomposition. Environmental Science and Technology 48:2843-2852

Mao Q, Ji F, Wang W, Hu Z, Yuan S (2016) Chlorination of parabens: reaction kinectics and transformation product identification. Environmental Science and Pollution Research 23:23081-2391

Marta-Sanchez AV, Caldas SS, Schneider A, Cardoso SMVS, Primel EG (2018) Trace analysis of parabens preservatives in drinking water treatment sludge, treated and mineral water samples. Environmental Science and Pollution Research International 25:14460-14470 
Margerum DW, Gray ET, Huffman RP (1978)Chlorination and the formation of N-chloro compounds in water treatment. In Organometals and organometalloids, American Chemicals Society. Chapter 17, pp 278-291.

Masten S (2005) Butylparaben [CAS n 94-26-8] Review of Toxicological Literature 1-64

Morris JC (1966) The acid ionization constant of $\mathrm{HOCl}$ frome 5 to $35^{\circ}$. Journal of Physical Chemistry 70:3798-3805

Oishi S (2001) Effects of butylparaben on the male reproductive system in rats. Toxicology and Industrial Health 17:31-39

Pattison DI, Davies MJ (2004) Kinetic analysis of the reactions of hypobromous acid with protein components: Implications for cellular damage and useof 3-bromotyrosine as a marker of oxidative stress. Biochemistry (Mosc) 43:4799-4809

Pouillot A, Polla AS, Polla BS (2006) Conservateurs en cosmétologie: Mise au point sur les parabènes. Le Journal de Médecine Esthétique et de Chirurgie Dermatologique 33 :187-190

Peng X, Yu Y, Tang C, Tan J, Huang Q, Wang Z (2008) Occurrence of steroid estrogens, endocrine-disrupting phenols and acid pharmaceutical residues in urban riverine water of the Pearl River Delta, South China. Science of the Total Environment 397:158-166

Qiang Z, Adams CD (2004) Determination of monochloramine formation rate constants with stopped-flow spectrophotometry. Environmental Science and Technology 38:1435-1444

Rebenne LM, Gonzalez AC, Olson TM (1996) Aqueous chlorination kinectics and mechanism of substituted dihydroxybenzenes. Environmental Science and Technology 30:2235-2242

Rodier J, Legube B, Merlet N (2009) Analysis of water, Dunod, Paris

Routledge EJ, Parker J, Odum J, Ashby J, Sumpter JP (1998) Some alkyl hydroxyl benzoate preservatives (parabens) are estrogenic. Toxicology and Applied Pharmacology 153:12-19

Sharma VK, Zboril R, McDonald TJ (2014) Formation and toxicity of brominated disinfection byproducts during chlorination of water: a review. Journal of Environmental Science and Health Part B 49:212-228 
Sivey JD, McCullough CE, Roberts AL (2010) Chlorine monoxide $\left(\mathrm{Cl}_{2} \mathrm{O}\right)$ and molecular chlorine $\left(\mathrm{Cl}_{2}\right)$ as active chlorinating agents in reaction of dimethenamid with aqueous free chlorine. Environmental Science and Technology 44:3357-3362

Soni MG, Carabin IG, Burdock GA (2005) Safety assessment of esters of p-hydroxybenzoic acid (parabens). Food Chemical Toxicology 43:985-1015

Symons JM, Krasner SW, Simms LA, Sclimenti M (1993) Measurement of THM and precursor concentrations revisited: The effect of bromide ion. Journal American Water Works Association 85:51-62

Tammilehto S, Büchi J (1968) Studies on the para-hydroxybenzoic acid ester (Nipagine). 1. Physical-chemical properties. Pharmaceutica Acta Helvetiae 43:726-738

Terasaki M, Makino M (2008) Determination of chlorinated by-products of parabens in swimming pool water. International Journal of Environmental and Analytical Chemistry 88: 911-922

Terasaki M, Takemura Y, Makino M (2012) Paraben chlorinated derivatives in river waters. Environmental Chemistry Letters 10:401-406

Troy RC, Margerum DW (1991) Non-metal redox kinetic hypobromite and hypobromous acid reactions with iodide and with sulfite and the hydrolysis of bromosulfate. Inorganic Chemistry 30:3538-3543

Vikesland PJ, Ozekin K, Valentine RL (2001) Monochloramine decay in model and distribution system waters. Water Research 35:1766-1776

Yoom H, Shin J, Ra J, Son H, Ryu D, Kim C, Lee Y (2018) Transformation of methylparaben during water chlorination: effects of bromide and dissolved organic matter on reaction kinetics and transformation pathways. Science of the Total Environment 634:677-686

Zhai H, Zhang X, Zhu X, Liu J, Ji M (2014) Formation of brominated disinfection byproducts during chloramination of drinking water. Environmental Science and Technology 48:25792588 
2 Fig. 1 Variation in the apparent second-order rate constants for MP reaction with chlorine (a) and

3 bromine (b) as a function of the $\mathrm{pH}$ level. Symbols show measured data and solid lines are the 4 modeled values of $\mathrm{k}_{\text {Oxidant/MP }}$ obtained using non-linear least squares regression. 5 (c) Comparison between chlorination and bromination rate constants and half-lives calculated by 6 considering $[\text { Oxidant }]_{\mathrm{T}}=14 \mu \mathrm{M}\left([\text { Chlorine }]_{\mathrm{T}}=1 \mathrm{mg} / \mathrm{L}\right.$ and $\left.[\text { Bromine }]_{\mathrm{T}}=2.2 \mathrm{mg} / \mathrm{L}\right)$

7 8
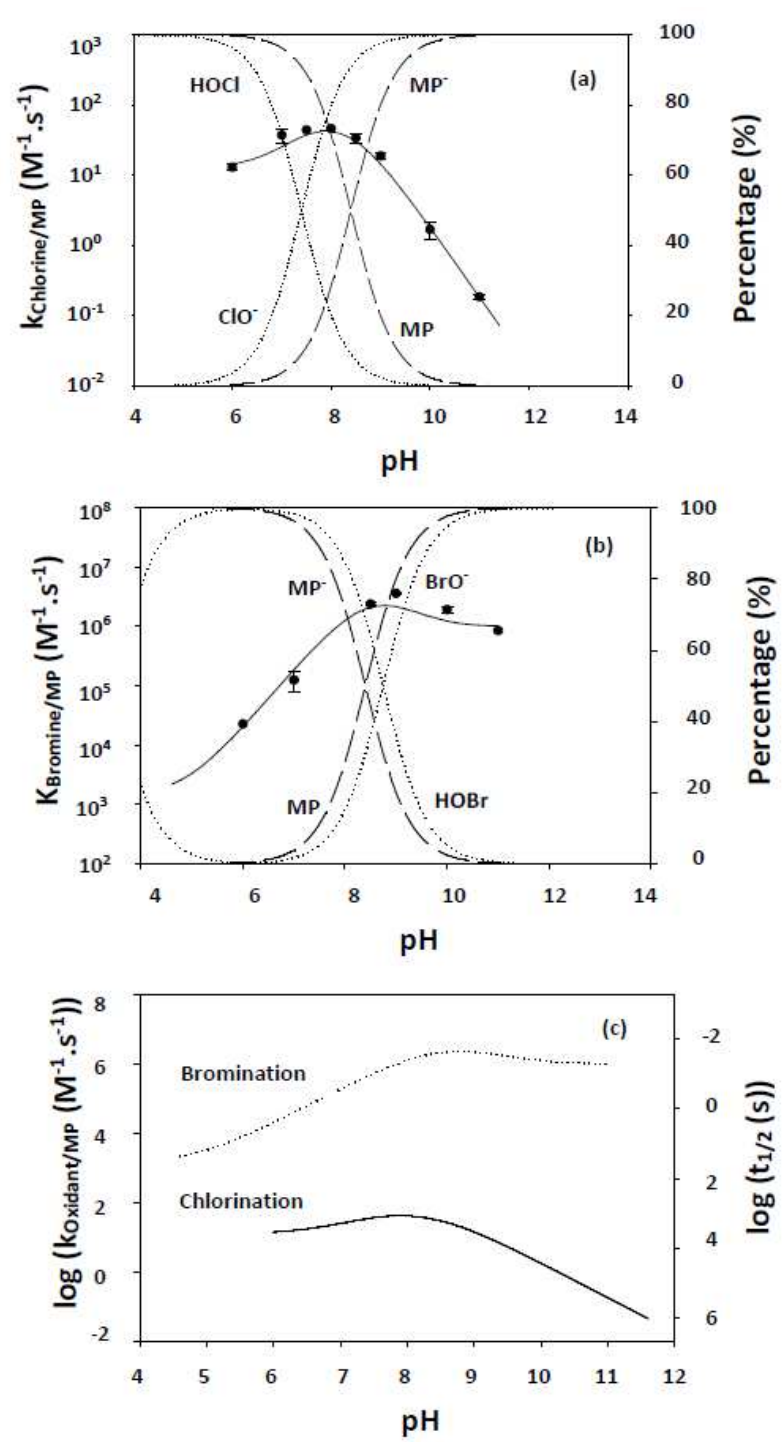
1 Fig. 2 Correlations between the second order rate constants for phenoxide ions reactions with

2 chlorine (a) and bromine (b) and the Hammett constants according to Duirk et al. (2013), Heeb et 3 al. (2014)

4

5

6

7

8

9

10

11

12

13

14

15

16

17
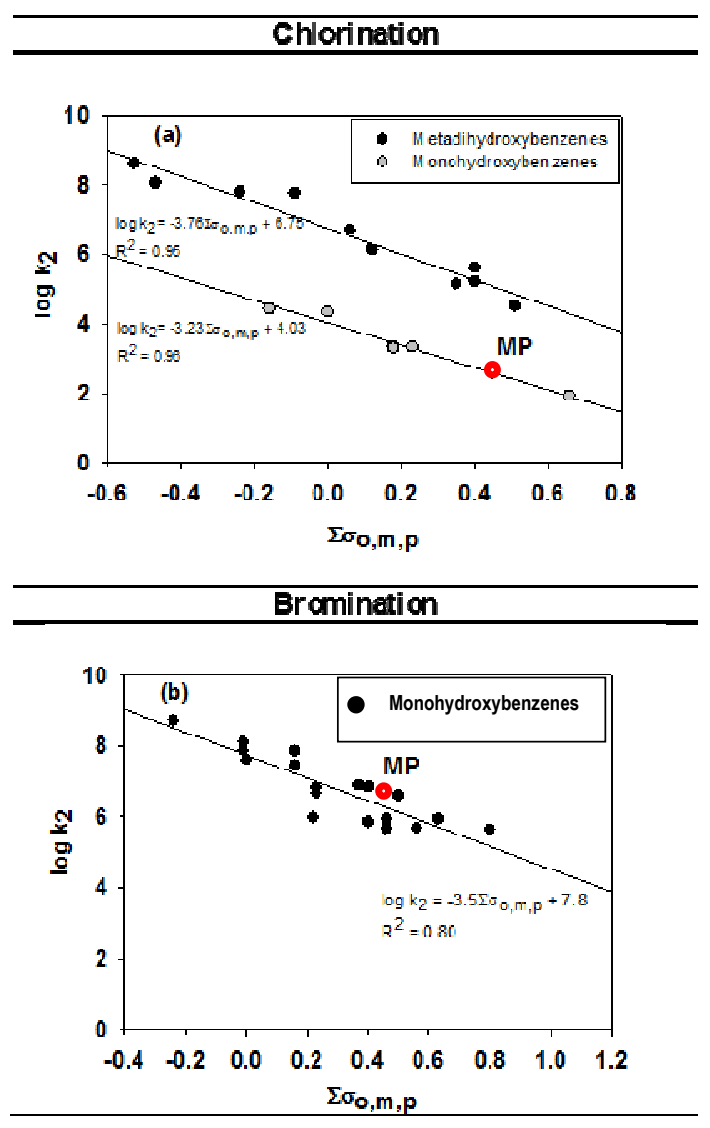
1 Fig. $3 \mathrm{MP}$ chlorination in the presence of $\mathrm{Br}^{-}$and/or ammonia at $\mathrm{pH} 7\left([\mathrm{MP}]_{\mathrm{T}, 0}=2( \pm 0.2) \mu \mathrm{M}\right.$,

$2[\text { Chlorine }]_{\mathrm{T}, 0}=10( \pm 1) \mu \mathrm{M}$; and $\left.\mathrm{T}=20 \pm 2^{\circ} \mathrm{C}\right)$. Symbols show experimental data and solid lines are

3 the modeling simulations obtained using Copasi software (Hoops et al. 2006)

4

5

6

7

8

9

10

\section{In the presence of bromide}

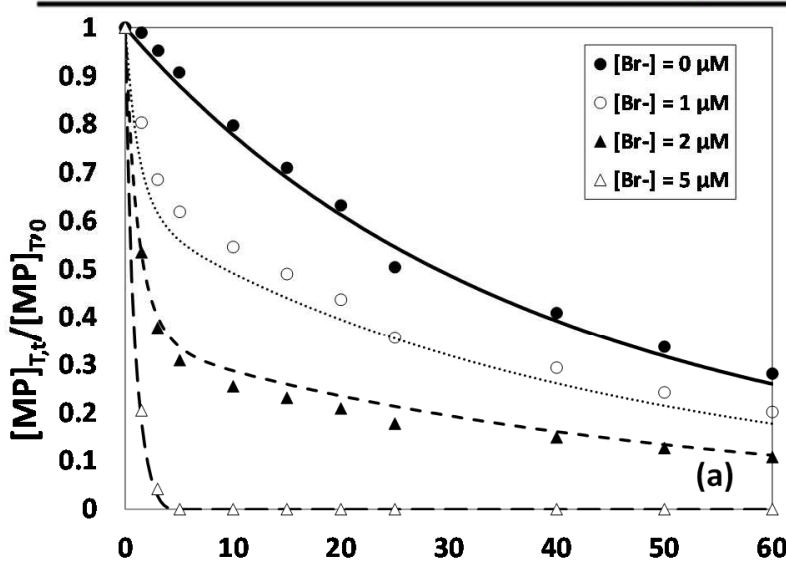

Time ( $\mathrm{min})$

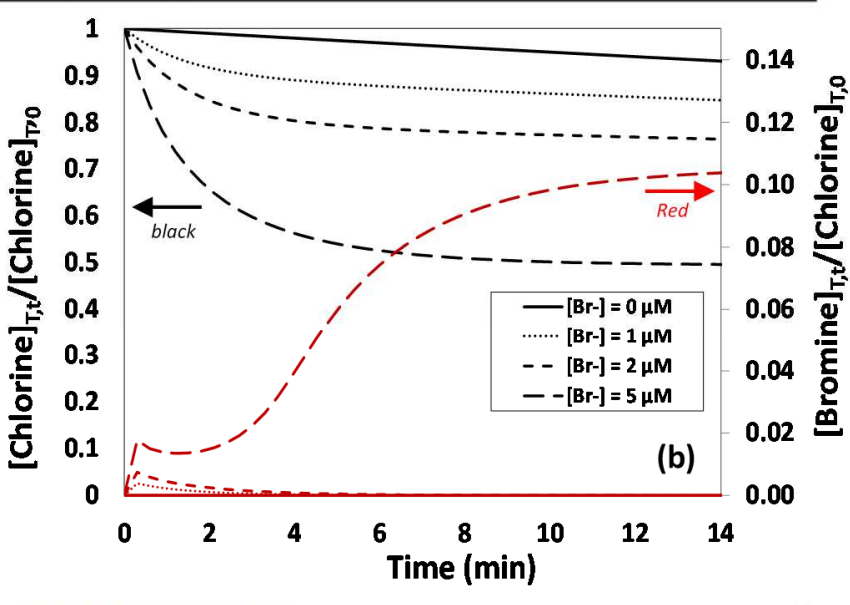

\section{In the presence of ammonia}

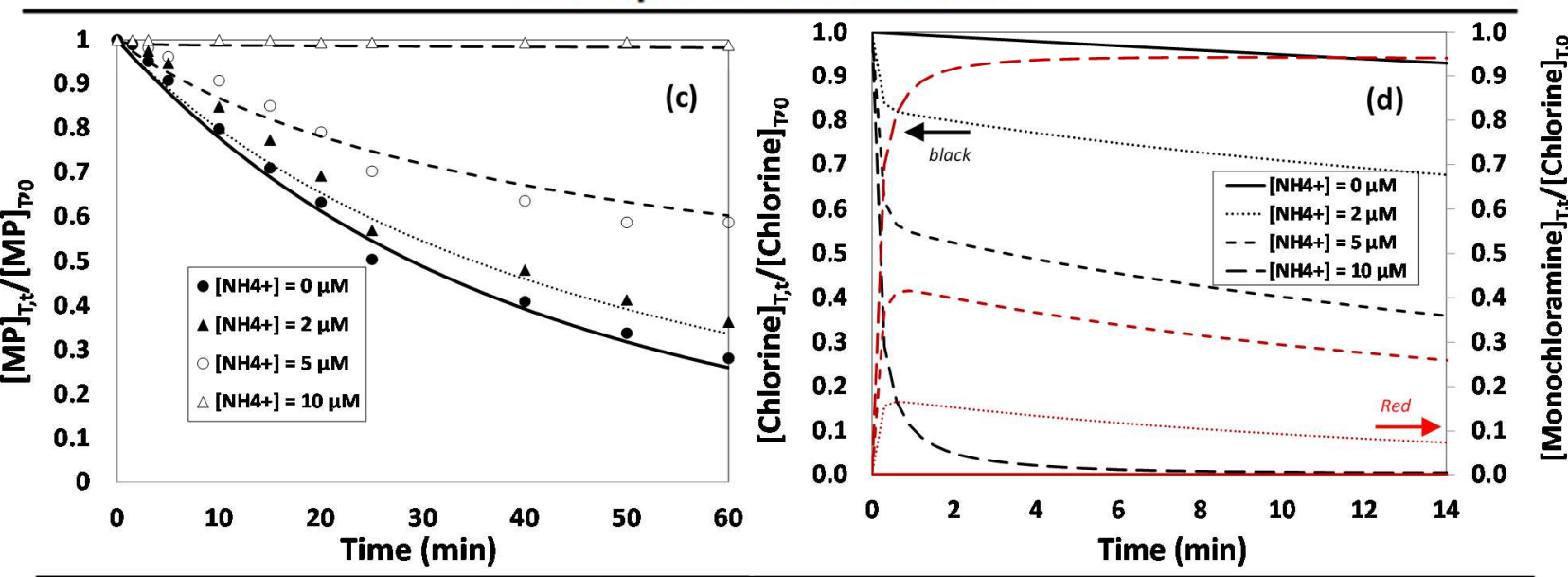

\section{In the presence of bromide and ammonia}
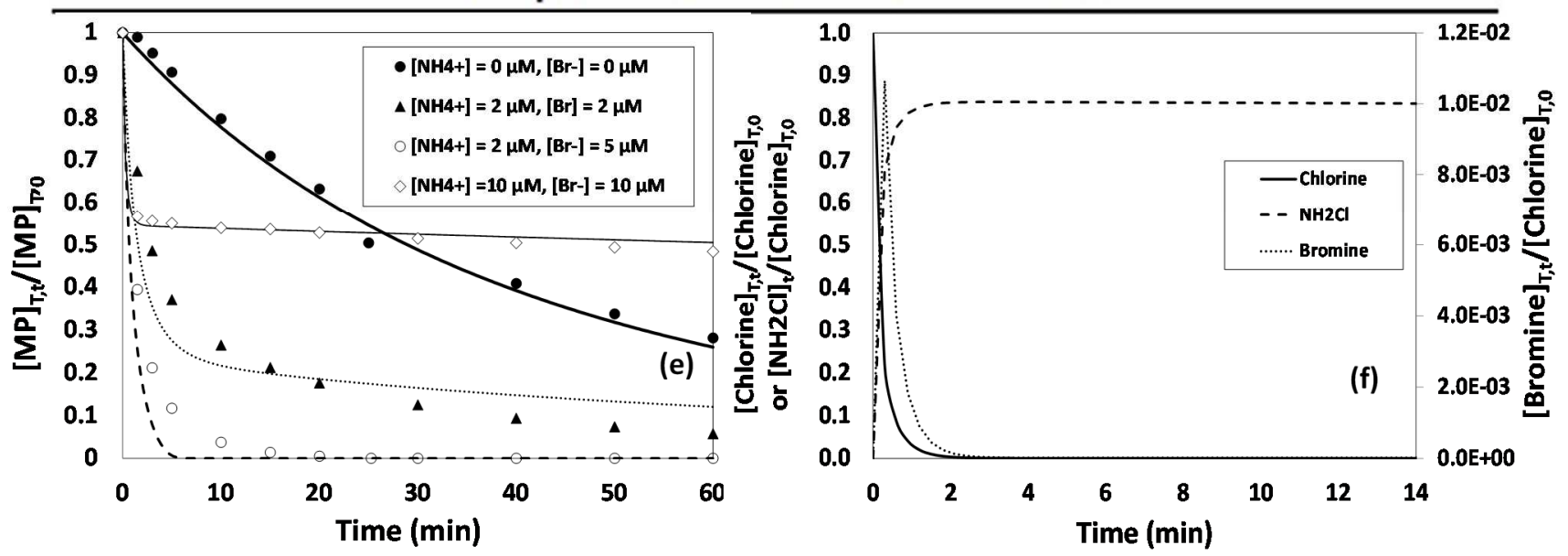
1 Fig. $4 \mathrm{MP}$ chlorination in the presence of $\mathrm{Br}^{-}$and/or ammonia at $\mathrm{pH} 8.5\left([\mathrm{MP}]_{\mathrm{T}, 0}=2( \pm 0,2) \mu \mathrm{M}\right.$,

$2[\text { Chlorine }]_{\mathrm{T}, 0}=10( \pm 1) \mu \mathrm{M}$; and $\left.\mathrm{T}=20 \pm 2^{\circ} \mathrm{C}\right)$. Symbols are experimental data and solid lines

3 represent the modeling simulations obtained using Copasi software (Hoops et al. 2006)

4
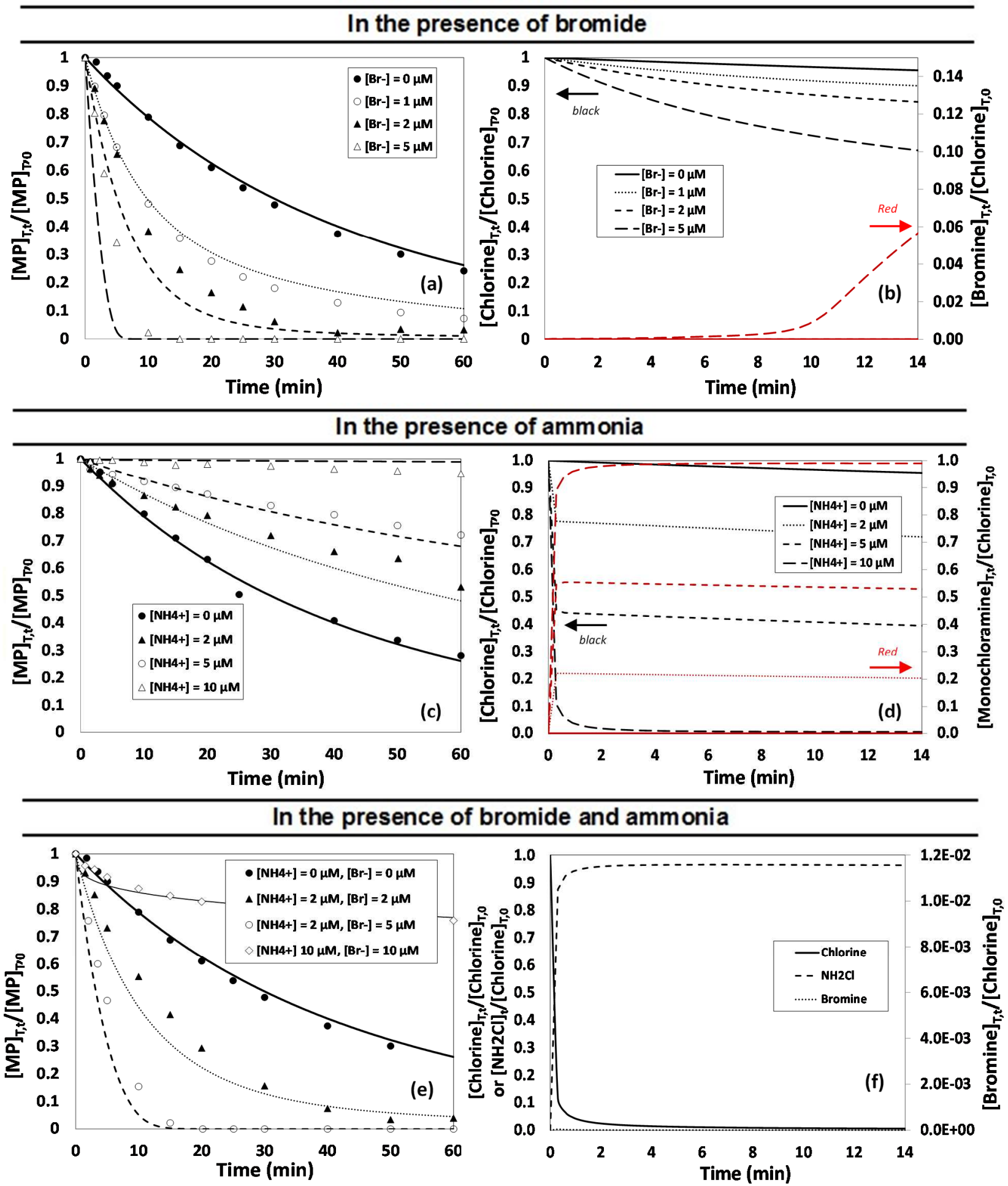
Fig. 5 Modeling of MP removal during chlorination in the presence of different $\mathrm{Br}^{-}$and ammonia

2 concentrations $\left.(\mathrm{t}=10 \min [\mathrm{MP}]=2 \mu \mathrm{M} \text {, [Chlorine }]_{\mathrm{T}}=10 \mu \mathrm{M}\right)$. (a) $\mathrm{pH}=7$; (b) $\mathrm{pH}=8.5$

3

4

5

6
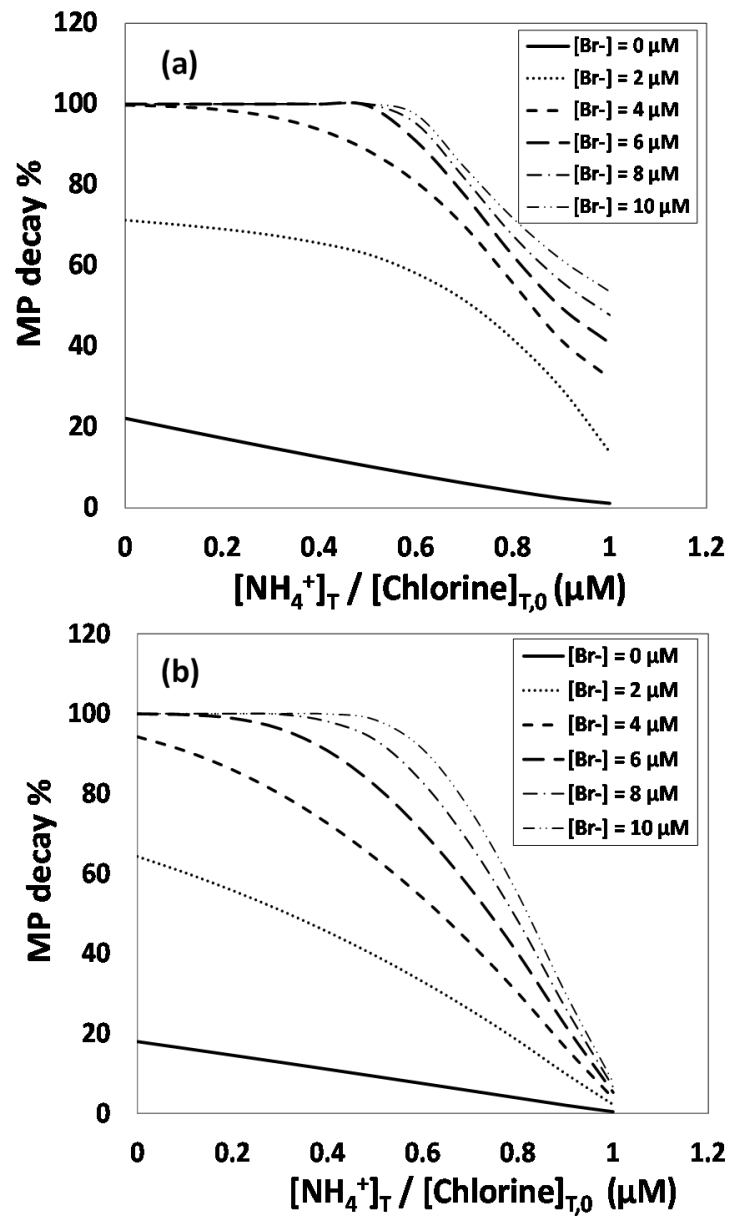
2 Table 1 List of elementary reactions considered for MP chlorination and bromination $(\mathrm{X}=\mathrm{Cl}$ or $\mathrm{Br})$

3

\begin{tabular}{lcccc}
\hline & Reactions & Chlorination & Bromination \\
\hline $\mathbf{1}$ & $\mathrm{HOX} \leftrightarrows \mathrm{XO}^{-}+\mathrm{H}^{+}$ & $\mathrm{pKa}_{1}$ & $7.54^{\mathrm{a}}$ & $8.89^{\mathrm{c}}$ \\
$\mathbf{2}$ & $\mathrm{MP} \leftrightarrows \mathrm{MP}^{-}+\mathrm{H}^{+}$ & $\mathrm{pKa}_{2}$ & & $8.4^{\mathrm{b}}$ \\
$\mathbf{3}$ & $\mathrm{HOX}+\mathrm{MP} \rightarrow$ products & $\mathrm{k}_{1}$ & $1.46( \pm 0.25) \times 10^{1} \mathrm{M}^{-1} \cdot \mathrm{s}^{-1}$ & $6.48( \pm 11.8) \times 10^{3} \mathrm{M}^{-1} \cdot \mathrm{s}^{-1}$ \\
$\mathbf{4}$ & $\mathrm{HOX}+\mathrm{MP}^{-} \rightarrow$ products & $\mathrm{k}_{2}$ & $5.60( \pm 0.43) \times 10^{2} \mathrm{M}^{-1} . \mathrm{s}^{-1}$ & $3.11( \pm 0.77) \times 10^{6} \mathrm{M}^{-1} . \mathrm{s}^{-1}$ \\
$\mathbf{5}$ & $\mathrm{XO}^{-}+\mathrm{MP} \rightarrow$ products & $\mathrm{k}_{3}$ & negligible & negligible \\
$\mathbf{6}$ & $\mathrm{XO}^{-}+\mathrm{MP}^{-} \rightarrow$ products & $\mathrm{k}_{4}$ & negligible & $1.03( \pm 0.26) \times 10^{6} \mathrm{M}^{-1} . \mathrm{s}^{-1}$
\end{tabular}

${ }^{\mathrm{a}}$ Morris 1966, ${ }^{\mathrm{b}}$ Tammilehto and Büchi 1968, ${ }^{\mathrm{c}}$ Lee and von Gunten 2009 
1 Table 2 Different reactions and apparent rate constants at $\mathrm{pH} 7$ and 8.5 considered for kinetic modeling of MP removal during chlorination in the

2 presence of $\mathrm{Br}^{-}$and ammonia

\begin{tabular}{|c|c|c|c|c|c|c|c|}
\hline \multirow{2}{*}{$\mathbf{N}^{\circ}$} & \multirow{2}{*}{ Reactions } & \multirow{2}{*}{$\begin{array}{l}\text { Transformation } \\
\text { Products }\end{array}$} & \multirow{2}{*}{$\sum \sigma_{o, m, p}$} & \multirow[t]{2}{*}{$\mathbf{p K a} \mathbf{a}^{\mathrm{f}}$} & \multirow[t]{2}{*}{$\mathbf{k}\left(\mathbf{M}^{-1} \cdot \mathbf{s}^{-1}\right)^{\mathbf{b}}$} & \multicolumn{2}{|c|}{ Apparent rate constant $\left(\mathbf{M}^{-1} \cdot \mathrm{s}^{-1}\right)$} \\
\hline & & & & & & pH 7 & pH 8.5 \\
\hline 1 & $\mathrm{HOCl}+\mathrm{MP}^{-}$ & $\mathrm{ClMP}^{-}$ & $0.45^{\mathrm{i}, \mathrm{j}}$ & $8.4^{\mathrm{h}}$ & $5.60 \times 10^{2 \mathrm{a}}$ & $4.30 \times 10^{1 \mathrm{a}}$ & $3.37 \times 10^{1 \mathrm{a}}$ \\
\hline 2 & $\mathrm{HOCl}+\mathrm{ClMP}^{-}$ & $\mathrm{Cl}_{2} \mathrm{MP}^{-}$ & $0.60^{\mathrm{i}, \mathrm{j}}$ & $7.0^{\mathrm{g}}$ & $1.23 \times 10^{2 \mathrm{c}}$ & $4.77 \times 10^{1 \mathrm{e}}$ & $1.18 \times 10^{1 \mathrm{e}}$ \\
\hline 3 & $\mathrm{HOCl}+\mathrm{Br}^{-}$ & $\mathrm{HOBr}+\mathrm{Cl}^{-}$ & - & - & $1.55 \times 10^{3 \mathrm{~m}}$ & $1.20 \times 10^{3 \mathrm{e}}$ & $1.53 \times 10^{2 \mathrm{e}}$ \\
\hline 4 & $\mathrm{HOBr}+\mathrm{MP}^{-}$ & $\mathrm{BrMP}^{-}$ & $0.45^{\mathrm{i}, \mathrm{j}}$ & $8.4^{\mathrm{h}}$ & $3.11 \times 10^{6 \mathrm{a}}$ & $1.25 \times 10^{5 \mathrm{a}}$ & $2.37 \times 10^{6 \mathrm{a}}$ \\
\hline 5 & $\mathrm{HOBr}+\mathrm{BrMP}^{-}$ & $\mathrm{Br}_{2} \mathrm{MP}^{-}$ & $0.60^{\mathrm{i}, \mathrm{j}}$ & $7.2^{\mathrm{g}}$ & $5.01 \times 10^{5 \mathrm{~d}}$ & $1.91 \times 10^{5 \mathrm{e}}$ & $3.39 \times 10^{5 \mathrm{e}}$ \\
\hline 6 & $\mathrm{HOCl}+\mathrm{BrMP}^{-}$ & $\mathrm{BrClMP}^{-}$ & $0.60^{\mathrm{i}, \mathrm{j}}$ & $7.2^{\mathrm{g}}$ & $1.23 \times 10^{2 \mathrm{~d}}$ & $3.69 \times 10^{1 \mathrm{e}}$ & $1.16 \times 10^{1 \mathrm{e}}$ \\
\hline 7 & $\mathrm{HOBr}+\mathrm{ClMP}^{-}$ & $\mathrm{BrClMP}^{-}$ & $0.60^{\mathrm{i}, \mathrm{j}}$ & $7.0^{\mathrm{g}}$ & $5.01 \times 10^{5 \mathrm{~d}}$ & $2.47 \times 10^{5} \mathrm{e}$ & $3.45 \times 10^{5 \mathrm{e}}$ \\
\hline 8 & $\mathrm{HOCl}+\mathrm{NH}_{3}$ & $\mathrm{NH}_{2} \mathrm{Cl}+\mathrm{H}_{2} \mathrm{O}$ & - & 9.25 & $3.07 \times 10^{6 \mathrm{k}}$ & $1.33 \times 10^{4 \mathrm{e}}$ & $4.58 \times 10^{4 \mathrm{e}}$ \\
\hline 9 & $\mathrm{NH}_{2} \mathrm{Cl}+\mathrm{H}_{2} \mathrm{O}$ & $\mathrm{NH}_{3}+\mathrm{HOCl}$ & - & - & $2.11 \times 10^{-5 \mathrm{k}}$ & & \\
\hline 10 & $\mathrm{HOCl}+\mathrm{NH}_{2} \mathrm{Cl}$ & $\mathrm{NHCl}_{2}+\mathrm{H}_{2} \mathrm{O}$ & - & - & $1.50 \times 10^{21}$ & $1.20 \times 10^{2 \mathrm{e}}$ & $1.53 \times 10^{1 \mathrm{e}}$ \\
\hline 11 & $\mathrm{NHCl}_{2}+\mathrm{H}_{2} \mathrm{O}$ & $\mathrm{NH}_{2} \mathrm{Cl}+\mathrm{HOCl}$ & - & - & $6.39 \times 10^{-71}$ & & \\
\hline 12 & $\mathrm{NH}_{2} \mathrm{Cl}+\mathrm{MP}^{-}$ & products & $0.45^{\mathrm{i}, \mathrm{j}}$ & $8.4^{\mathrm{h}}$ & _ & $<0.045^{\mathrm{a}}$ & $0.045^{\mathrm{a}}$ \\
\hline
\end{tabular}

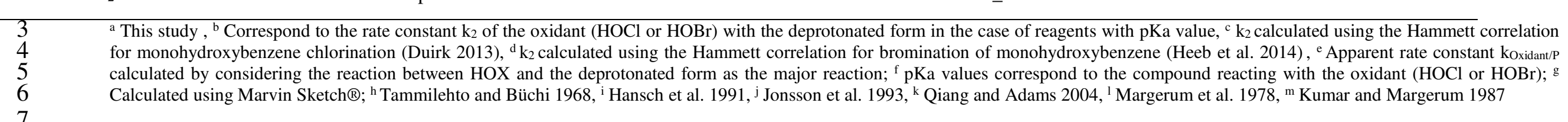

